\title{
Effects of glucose and protein sources on bovine embryo development in vitro
}

\author{
E. Gomez ${ }^{*}$, C. Diez \\ Centro de Selección y Reproducción Animal, CIATA, Consejería de Agricultura, Camino de los Claveles s / n. \\ SOMIO, 33203 Gijon Asturias, Spain
}

Received 9 December 1998; received in revised form 21 April 1999; accepted 11 October 1999

\begin{abstract}
Oviductal factors may be obtained by ultrafiltration of conditioned medium, added to a simple media and used in bovine embryo culture. In this study, we aimed to analyze the development of bovine embryos produced with oviductal factors compared to those cultured in the presence of BSA or serum, the effects of glucose in presence of these protein supplements, and the ability of oviductal factors to support embryo development during the entire culture period. In vitro produced bovine zygotes from slaughterhouse ovaries were cultured in modified-synthetic oviduct fluid (mSOF) alone or supplemented with (1) oviductal factors, (2) BSA and (3) FCS. Oviductal factors showed embryotrophic activity, although with blastocyst rates lower than those in BSA and FCS. Glucose $(1.5 \mathrm{mM})$ added at Day 2 of culture did not affect development in the presence of oviductal factors. The number of cells in expanded blastocysts was unaffected by the presence of glucose or any of the protein supplements used. Both BSA and FCS, respectively, improved blastocyst rates of Day 6 embryos produced with oviductal factors. The effect of oviductal factors was masked by the presence of BSA during the entire culture. FCS promoted an earlier appearance of blastocysts. It is concluded that the effect of glucose on in vitro embryo development depends upon the source of protein. Oviductal factors are not an appropriate supplement for embryos beyond Day 6 of culture in SOF, although blastocyst rates of such embryos may be increased by culturing them in the presence of FCS or BSA. (C) 2000 Elsevier Science B.V. All rights reserved.
\end{abstract}

Keywords: Cattle-reproductive technology; Serum; Albumin; Oviduct; Glucose; In vitro bovine embryo

\footnotetext{
* Corresponding author. Tel.: +34-985-195300; fax: +34-985-195310.

E-mail address: enriquegp@princast.es (E. Gomez).
} 


\section{Introduction}

Although bovine embryos can be cultured in vitro in simple media under defined conditions (Pinyopummintr and Bavister, 1991; Kim et al., 1993b; Lim et al., 1994a; Keskintepe et al., 1995; Takahashi et al., 1996; Matsui et al., 1997), protein supplementation has been shown to be beneficial for embryo development in vitro (Takahashi and First, 1992; Carolan et al., 1995). Embryos cultured in the absence of protein exhibit differences in their metabolic activity (Eckert et al., 1998; Krisher et al., 1998; Lee et al., 1998), diminished developmental capacity (Eckert et al., 1998; Krisher et al., 1998), lower protein contents (Thompson et al., 1998b) and a lower cell number (Pinyopummintr and Bavister, 1991; Lim et al., 1994b; Lee et al., 1998) compared to those cultured in the presence of protein. In addition, protein in the extra-embryonic environment is actively taken up by the trophectoderm of Day 7 blastocysts (Thompson et al., 1998b). Serum and serum albumin are used preferentially as protein sources for the in vitro culture of mammalian embryos. Serum may present negative side effects (Bavister, 1995), which are minimized by incorporating serum albumin into the culture media, due in part to its ligand binding properties protecting against toxic components of the media (Flood and Shirley, 1991; Maurer, 1992).

Recently, Vansteenbrugge et al. (1996) demonstrated that high molecular weight factors, isolated from bovine oviductal cells cultured in vitro, improve embryo development. These factors, obtained by ultrafiltration (10 kDa cut off) of serum free, TCM-199 conditioned medium, were used in culture as a protein supplement, being added to synthetic oviduct fluid medium (SOF). That work demonstrated the specificity of the effect of oviductal factors by means of a comparison with proteins such as cytochrome C and ovalbumin. In the same work, the complex medium TCM-199, necessary for sustaining somatic cells in culture, was unsuitable for preimplantation embryos, as pointed out by Edwards et al. (1997).

The development of bovine embryos in vitro is also affected by energy substrates (Kim et al., 1993b; Rosenkrans et al., 1993; Pinyopummintr and Bavister, 1996; Gómez, 1997; Gómez and Díez, 1998). In particular, glucose at concentrations ranging from 1.5 to $5.56 \mathrm{mM}$, has been reported to improve blastocyst production both in presence of serum (Rorie et al., 1994; Carolan et al., 1995; Koji et al., 1997; Wang et al., 1997; Donnay et al., 1999) and in the presence of BSA (Kim et al., 1993a; Lim et al., 1993, 1994a; Ohboshi et al., 1996; Furnus et al., 1997). Pyruvate, lactate and amino acids, are preferred to glucose during the early cleavage stages (Rieger et al., 1992a,b; Pinyopummintr and Bavister, 1996). Thus, the stimulatory effect of glucose is generally described in association with its delayed incorporation in culture (Kim et al., 1993a; Lim et al., 1994a; Ohboshi et al., 1996; Furnus et al., 1997; Donnay et al., 1999).

Factors required to reach the morula and blastocyst stage may be lacking in oviductal factors from some batches of conditioned medium, and limited development to the blastocyst stage of such cultured embryos was observed in preliminary studies (Díez et al., 1998). Oviductal factors have not been tested in culture in comparison with BSA and FCS, and the effect of glucose on embryo development in medium containing oviductal factors is not still known. 
In the present work, we aimed to develop a procedure allowing the storage of a frozen retentate containing oviductal factors. This is in place of repeating centrifugation of frozen-stored aliquots of conditioned medium, which is a time-consuming operation (Vansteenbrugge et al., 1996). In addition, in order to enhance the number and nature of molecules present in the retentate, the cut off employed was $1 \mathrm{kDa}$. These factors were compared to other protein supplements in terms of their embryotrophic ability. At the same time, the effect of glucose on embryo development and its dependence on the nature of protein supplements employed was tested. Finally, we determined whether or not embryos cultured with oviductal factors as a protein supplement for the entire culture exhibit diminished developmental competence.

\section{Materials and methods}

All chemicals were purchased from Sigma (Madrid, Spain), unless otherwise indicated.

\subsection{Preparation of bovine oviductal cell conditioned medium (BOCM)}

Procedures to prepare conditioned medium were a modification to those reported by Eyestone and First (1989). Briefly, oviducts were dissected free from adjacent tissues and treated for $30 \mathrm{~s}$ in ethanol $(70 \% \mathrm{v} / \mathrm{v})$ in water. Oviducts were filled with Hank's solution $\left(\mathrm{Ca}^{2+}\right.$ and $\mathrm{Mg}^{2+}$ free) and clamped over both extremes. A gentle pressure along the oviducts prior to clamp removal permitted the collection of medium with aggregates of epithelial cells. These aggregates were pipetted to a tube containing the culture medium, that consisted of TCM-199 (Gibco, Barcelona, Spain), 10\% FCS and antibiotic-antimycotic. The cells suspended in the culture medium were dispersed by passing them through a 25-gauge needle attached to a syringe and centrifuged once at $700 \times g$ for $4 \mathrm{~min}$. A sample from the final cell pellet was counted in an haemocytometer, and aliquots of $10 \mathrm{ml}$ of culture medium containing $10^{6}$ cells were seeded in $25-\mathrm{cm}^{2}$ culture flasks (Nunc, Biocen, Madrid, Spain). The cell suspension was incubated at $39^{\circ} \mathrm{C}$, in an atmosphere of $5 \% \mathrm{CO}_{2}$ in air and high humidity. The culture medium was renewed 3-4 days after seeding, and attached cells were allowed to grow in culture during a further period of 3 days to form a confluent monolayer. The cell monolayers were then incubated for $48 \mathrm{~h}$ in TCM-199 alone to eliminate remaining serum fractions. The medium was aspirated and discarded and the cell-monolayers rinsed once with TCM-199 alone. For conditioning, $6 \mathrm{ml}$ of TCM-199 alone were added per flask in successive culture periods of $48 \mathrm{~h}$ each.

\subsection{Ultrafiltration of BOCM}

A modification of the procedure of Vansteenbrugge et al. (1996) was used. The first three harvests of conditioned medium were pooled, stored at $4^{\circ} \mathrm{C}$ and rapidly dialyzed in an ultrafiltration cell pressurized with $\mathrm{N}_{2}$. Every batch of conditioned medium was dialyzed four times against Milli-Q water trough a 1000 Da cut-off membrane (regener- 
ated cellulose, low binding, cat \# 04710, Millipore, Madrid, Spain). The final volume of retentate was reduced to $1 / 10$ of the initial volume in the original conditioned medium. Retentate was sterile filtered through $0.22 \mu \mathrm{m}$, aliquoted in cryovials containing $200 \mu \mathrm{l}$ each and stored frozen in $\mathrm{LN}_{2}$ until use.

\subsection{Glucose and protein contents}

The protein content of retentate was quantified in the frozen/thawed aliquots using the Coomassie blue method (Bradford, 1976). The glucose content was determined in frozen/thawed aliquots of retentate and also in FCS and in a 32-mg/ml solution of BSA. The method of analysis was colorimetric, by the stoichiometric production of NADPH in the hexokinase, glucose 6-phosphate dehydrogenase reaction, coupled with reduction of iodonitrotetrazolium on an autoanalyzer.

\subsection{Oocyte recovery}

Ovaries recovered from slaughtered Asturiana de los Valles cows and heifers were placed in $\mathrm{NaCl}$ solution $\left(9 \mathrm{mg} \mathrm{ml}^{-1}\right.$ ) containing antibiotics (penicillin, $100 \mathrm{u} . \mathrm{i} . \mathrm{ml}^{-1}$ and streptomycin sulfate, $100 \mu \mathrm{g} \mathrm{ml}^{-1}$ ) and maintained at $30-35^{\circ} \mathrm{C}$ until recovery of cumulus-oocyte complexes (COCs). Ovaries were washed twice in distilled water and once in freshly prepared saline and antibiotics. COCs were aspirated from 2- to 7-mm visible follicles through an 18-gauge needle connected to a syringe and recovered into a 50-ml plastic tube. Follicular fluid and COCs were placed in an ovum concentrator (Em-Con, Eurofomento Pecuario, Madrid, Spain) and rinsed three times with holding medium, consisting of PBS, pyruvate $0.16 \mathrm{mM}$, BSA $3 \mathrm{mg} \mathrm{ml}^{-1}$ and gentamycin solution $\left(5 \mu 1 \mathrm{ml}^{-1}\right.$; Gibco).

\subsection{Maturation}

Only oocytes enclosed in a compact cumulus with evenly granulated cytoplasm were selected for maturation. The COCs were washed three times in maturation medium, which consisted of Medium 199 (Sigma), fetal bovine serum (FBS, 10\% v/v), FSHp (1 $\left.\mu \mathrm{g} \mathrm{ml}^{-1}\right)$, LH $\left(5 \mu \mathrm{g} \mathrm{ml}^{-1}\right), 17$ - $\beta$-estradiol $\left(1 \mu \mathrm{g} \mathrm{ml}^{-1}\right)$ and cysteamine $(100 \mu \mathrm{M})$. Maturation was performed by culturing approximately $50 \mathrm{COCs}$ in $500 \mu \mathrm{l}$ of maturation medium in four-well dishes at $39^{\circ} \mathrm{C}$ in $5 \% \mathrm{CO}_{2}$ in air and high humidity.

\subsection{Fertilization}

Sperm separation was carried out using a swim-up procedure similar to that reported by Parrish et al. (1986). Briefly, semen from one frozen straw of a single bull was thawed in a water bath and added to a polystyrene tube containing $1 \mathrm{ml}$ of pre-equilibrated Sperm-TALP. After $1 \mathrm{~h}$ of incubation, approximately $700 \mu \mathrm{l}$ of the upper layer of supernatant containing the motile sperm was removed. The sperm were centrifuged for $7 \mathrm{~min}$ at $600 \mathrm{rpm}$ and the supernatant aspirated to leave a pellet of approximately $100 \mu \mathrm{l}$ in volume. Sperm concentration was determined with a haemocytometer. After 
23 to $24 \mathrm{~h}$ of maturation, the COCs were washed three times in holding medium and placed in four-well culture dishes containing pre-equilibrated fertilization medium (Fert-TALP) with heparin (10 $\mu \mathrm{g} \mathrm{ml}^{-1}$, Calbiochem, La Jolla, CA). Spermatozoa were then added at a concentration of $2 \times 10^{6}$ cells $\mathrm{ml}^{-1}$ in $500 \mu \mathrm{l}$ of medium per well containing $100 \mathrm{COCs}$. In vitro fertilization was accomplished by incubating oocytes and sperm cells together for $18 \mathrm{~h}$ at $39^{\circ} \mathrm{C}$ in $5 \% \mathrm{CO}_{2}$ in air and high humidity.

\subsection{Embryo culture}

Embryo culture was carried out in mSOF (270-280 mosM, pH 7.2-7.3; Takahashi and First, 1992), containing $20 \mathrm{ml} / 1$ BME essential amino acids, $10 \mathrm{ml} / 1 \mathrm{MEM}$ nonessential amino acids, cysteamine $50 \mu \mathrm{M}$ and a protein supplement. According to the protein supplement added, culture groups used throughout the experiments were as follows: (1) FCS: mSOF containing BSA $\left(3 \mathrm{mg} \mathrm{ml}^{-1}\right)$ and FCS $(10 \% \mathrm{v} / \mathrm{v}),(2) \mathrm{BSA}$ : mSOF supplemented with BSA $\left(8 \mathrm{mg} \mathrm{ml}^{-1}\right)$, (3) UBOCM: To get mSOF containing ultrafiltered BOCM, a cryovial of retentate was thawed and filled with $1800 \mu \mathrm{l}$ of a sterile filtered $\mathrm{mSOF}$, which was previously concentrated to approximately $9 / 10$ in volume and adjusted to $303 \operatorname{mosM}$ and $\mathrm{pH} 7.1$. The cryovial was centrifuged for $5 \mathrm{~min}$ at $2000 \times g$ and the supernatant used for embryo culture; and (4) UBOCM + BSA: UBOCM and $8 \mathrm{mg} \mathrm{ml}^{-1}$ BSA.

Droplets of $30-50 \mu \mathrm{l}\left(1 \mu \mathrm{l}\right.$ embryo $\left.^{-1}\right)$ of culture medium were prepared in four-well dishes under mineral oil and equilibrated in the incubator for at least $2 \mathrm{~h}$ prior to the addition of zygotes.

Fertilized oocytes were vortexed for $3 \mathrm{~min}$ to separate cumulus cells and rapidly washed three times in holding medium and twice in the appropriate culture medium. Culture media were renewed for three times during the culture period. Embryo development was observed on Days 2, 3, 6, 7, 8, and 9 post-insemination (PI).

\subsection{Cell counts}

The cell numbers of expanded blastocyst obtained at Day 7 and 8 were measured. Blastocysts were maintained for $20 \mathrm{~min}$ in hypotonic solution $(0.9 \% \mathrm{w} / \mathrm{v}$ of sodium citrate in double distilled water), fixed with methanol and acetic acid (2:1), and stained with Giemsa $(1 / 20 \mathrm{v} / \mathrm{v})$ for $25 \mathrm{~min}$. Cell counting was carried out at $\times 200$ under a light microscope.

\subsection{Experimental design}

\subsubsection{Experiment I}

To determine embryotrophic ability of the retentate, in vitro development of embryos cultured in UBOCM was compared to that of embryos cultured in the absence of protein supplements.

\subsubsection{Experiment II}

The effect of the presence of glucose $(1.5 \mathrm{mM}$ added to the culture media $68 \mathrm{~h} \mathrm{PI})$ and protein supplements (FCS, BSA and UBOCM) on the embryo development and 
Table 1

Embryotrophic ability of ultrafiltered serum-free, oviduct conditioned medium (UBOCM) added to mSOF, measured as development rates of cultured embryos against mSOF containing no protein

Values in the same column with different superscripts differ statistically.

Results correspond to three replicate.

\begin{tabular}{llllrc}
\hline Treatment & Oocytes & \% Cleaved & \% Five to eight cells & \% Morulae & \% Blastocysts \\
\hline UBOCM & 85 & $81.5 \pm 8.0$ & $57.68 \pm 6.6$ & $35.1 \pm 3.5^{\mathrm{a}}$ & $17.8 \pm 0.9^{\mathrm{x}}$ \\
No protein & 88 & $69.0 \pm 8.0$ & $34.73 \pm 5.8$ & $7.0 \pm 2.7^{\mathrm{b}}$ & $1.3 \pm 1.2^{\mathrm{y}}$ \\
\hline
\end{tabular}

${ }^{\mathrm{a}} p<0.05$.

${ }^{\mathrm{b}} p<0.05$.

${ }^{\mathrm{x}} p<0.01$.

${ }^{\mathrm{y}} p<0.01$.

number of cells was analyzed in a $3 \times 2$ factorial design. In this experiment, serum in the FCS group was added $42 \mathrm{~h} \mathrm{PI}$.

\subsubsection{Experiment III}

The capacity of Day 6 embryos cultured in UBOCM (129 h PI) to resume development in the presence of albumin, and the effect of albumin together with UBOCM, were analyzed. Supplements in culture groups were as follows: (1) BSA for the entire culture period, (2) UBOCM for the entire culture period, (3) BSA + UBOCM for the entire culture period and (4) UBOCM up to Day 6 (129 h PI) and BSA from Day 6 to the end of culture (BSA > UBOCM).

\subsubsection{Experiment $I V$}

The capacity of Day 6 embryos cultured in UBOCM to resume development in the presence of serum was evaluated. Zygotes were randomly allocated to culture medium that contained one of the following supplements: (1) FCS for the whole culture period,

Table 2

In vitro development and expanded blastocyst cell counts of bovine embryos cultured in mSOF containing $10 \%$ serum (FCS), $8 \mathrm{~g} / 1$ albumin (BSA) and ultrafiltered serum-free, oviduct conditioned medium (UBOCM) Data from 12 replicates. $n$ : Number of oocytes.

Values in the same column with different superscripts differ statistically.

\begin{tabular}{llllllll}
\hline Treatment & $n$ & \% Morulae & \multicolumn{2}{l}{ \% Blastocysts } & & \\
\cline { 4 - 8 } & & Day 6 & Day 6 & Day 7 & Day 8 & Day 9 & No nuclei \\
\hline FCS & 262 & $42.4 \pm 3.0^{\mathrm{a}}$ & $14.7 \pm 2.9^{\mathrm{a}}$ & $26.9 \pm 3.8^{\mathrm{x}}$ & $29.2 \pm 3.8^{\mathrm{a}}$ & $32.0 \pm 4.3^{\mathrm{a}}$ & $89.7 \pm 5.2$ \\
BSA & 270 & $34.2 \pm 3.9^{\mathrm{b}}$ & $2.6 \pm 1.1^{\mathrm{b}}$ & $17.8 \pm 3.0^{\mathrm{y}}$ & $23.1 \pm 3.8^{\mathrm{b}}$ & $24.5 \pm 4.1^{\mathrm{b}}$ & $82.4 \pm 5.9$ \\
UBOCM & 265 & $34.4 \pm 5.0^{\mathrm{b}}$ & $0.0^{\mathrm{b}}$ & $9.0 \pm 2.4^{\mathrm{z}}$ & $16.2 \pm 3.9^{\mathrm{c}}$ & $17.0 \pm 4.4^{\mathrm{c}}$ & $90.6 \pm 5.1$ \\
\hline
\end{tabular}

$$
\begin{aligned}
& { }^{\mathrm{a}} p<0.05 . \\
& { }^{\mathrm{b}} p<0.05 . \\
& { }^{\mathrm{c}} p<0.05 . \\
& { }^{\mathrm{x}} p<0.01 . \\
& { }^{\mathrm{y}} p<0.01 . \\
& { }^{\mathrm{z}} p<0.01 .
\end{aligned}
$$


Table 3

Effect of glucose $1.5 \mathrm{mM}$ added to the culture media $68 \mathrm{~h}$ PI on morulae and blastocyst development of embryos cultured in mSOF containing $10 \%$ serum (FCS)

Data from 13 replicates. $n$ : Number of oocytes.

Values in the same column with different superscripts differ statistically.

\begin{tabular}{|c|c|c|c|c|c|c|c|}
\hline \multirow[t]{2}{*}{ FCS } & \multirow[t]{2}{*}{$n$} & \multirow{2}{*}{$\begin{array}{l}\% \text { Morulae } \\
\text { Day } 6\end{array}$} & \multicolumn{5}{|c|}{$\%$ Blastocysts } \\
\hline & & & Day 6 & Day 7 & Day 8 & Day 9 & No nuclei \\
\hline Glucose (+) & 280 & $45.2 \pm 4.1$ & $14.2 \pm 3.2$ & $36.9 \pm 3.6^{\mathrm{a}}$ & $39.1 \pm 4.0^{x}$ & $41.2 \pm 3.5^{\mathrm{a}}$ & $79.9 \pm 4.2$ \\
\hline Glucose $(-)$ & 274 & $42.8 \pm 3.7$ & $13.3 \pm 3.3$ & $28.4 \pm 3.8^{b}$ & $30.0 \pm 3.6^{\mathrm{y}}$ & $33.2 \pm 4.1^{\mathrm{b}}$ & $88.4 \pm 6.4$ \\
\hline
\end{tabular}

${ }^{\mathrm{a}} p<0.05$.

${ }^{\mathrm{b}} p<0.05$.

${ }^{\mathrm{x}} p<0.01$.

${ }^{\mathrm{y}} p<0.01$.

(2) UBOCM for the whole culture period and (3) UBOCM up to Day 6 (129 h PI) and FCS from Day 6 to the end of culture.

\subsection{Statistical analysis}

Data were analyzed by ANOVA. Combination of treatments was considered as fixed effects for the different developmental variables. The Tukey's test was used to estimate the significance of treatment effects, which were expressed as mean percentages of the cultured oocytes or number of cells in blastocysts.

\subsection{Ultrafiltration}

Four batches of UBOCM were selected for their embryotrophic activity to be used throughout the experiments (Vansteenbrugge et al., 1996; Díez et al., 1998). Final osmolarity and $\mathrm{pH}$ in $\mathrm{mSOF}$ containing UBOCM ranged between 280 and $286 \mathrm{mosM} / \mathrm{kg}$, and 7.24 and 7.29 , respectively.

\subsection{Glucose and protein contents}

Data refer to concentrations of the respective supplements as used in culture. The total protein content of the retentate (mean of five batches) was $83 \mu \mathrm{g} / \mathrm{ml}$ on average.

Table 4

Effect of glucose $1.5 \mathrm{mM}$ added to the culture media $68 \mathrm{~h}$ PI on morulae and blastocyst development of embryos cultured in mSOF containing $8 \mathrm{~g} / 1$ albumin (BSA)

Data from 15 replicates. $n$ : Number of oocytes.

Values in the same column with different superscripts differ statistically.

\begin{tabular}{|c|c|c|c|c|c|c|c|}
\hline \multirow[t]{2}{*}{ BSA } & \multirow[t]{2}{*}{$n$} & \multirow{2}{*}{$\begin{array}{l}\% \text { Morulae } \\
\text { Day } 6\end{array}$} & \multicolumn{5}{|c|}{$\%$ Blastocysts } \\
\hline & & & Day 6 & Day 7 & Day 8 & Day 9 & No nuclei \\
\hline Glucose $(+)$ & 329 & $39.7 \pm 4.1^{\mathrm{a}}$ & $3.9 \pm 1.7$ & $19.0 \pm 3.0$ & $27.9 \pm 3.3^{\mathrm{a}}$ & $28.4 \pm 3.4^{\mathrm{a}}$ & $82.2 \pm 4.6$ \\
\hline Glucose $(-)$ & 325 & $32.8 \pm 4.3^{\mathrm{b}}$ & $2.2 \pm 1.2$ & $17.7 \pm 3.2$ & $21.2 \pm 3.9^{\mathrm{b}}$ & $22.8 \pm 4.1^{\mathrm{b}}$ & $90.1 \pm 4.4$ \\
\hline
\end{tabular}

$$
\begin{aligned}
& { }^{\mathrm{a}} p<0.05 . \\
& { }_{p} p<0.05 .
\end{aligned}
$$


Table 5

Effect of glucose $1.5 \mathrm{mM}$ added to the culture media $68 \mathrm{~h}$ PI on morulae and blastocyst development of embryos cultured in mSOF containing ultrafiltered serum-free, oviduct conditioned medium (UBOCM)

Data from 12 replicates. $n$ : Number of oocytes. No differences were observed $(p>0.05)$.

\begin{tabular}{llllllll}
\hline UBOCM & $n$ & \multirow{2}{*}{$\begin{array}{l}\text { \% Morulae } \\
\text { \% Blastocysts }\end{array}$} & \multicolumn{2}{l}{} \\
\cline { 4 - 7 } & & Day 6 & Day 6 & Day 7 & Day 8 & Day 9 & No nuclei \\
\hline Glucose (+) & 301 & $34.1 \pm 3.2$ & 0.0 & $9.3 \pm 1.8$ & $16.5 \pm 3.7$ & $18.4 \pm 4.1$ & $92.4 \pm 6.0$ \\
Glucose (-) & 298 & $35.7 \pm 4.8$ & 0.0 & $9.8 \pm 2.9$ & $16.8 \pm 4.0$ & $19.2 \pm 4.1$ & $87.0 \pm 5.9$ \\
\hline
\end{tabular}

The average glucose content was $0.55 \mathrm{mM}$ (serum, three batches), $\leq 0.12 \mathrm{mM}$ (BSA, one batch used in all experiments) and $\leq 0.05 \mathrm{mM}$ (retentate, four batches).

\subsection{Cleavage and five to eight cell stage}

Table 1 shows differences at these stages between embryos cultured in UBOCM and embryos cultured in the absence of protein. In the tables corresponding to the other experiments, cleavage and five to eight cell stage ranged from 81.81 to 89.58 and 57.51 to 64.82 , respectively, with no significant differences being detected.

\subsubsection{Experiment I}

Embryos cultured in the presence of oviductal factors developed to the morula and blastocyst stages at higher rates than those cultured in the absence of protein supplements (see Table 1)

\subsubsection{Experiment II}

Results are shown in Tables 2-5. Glucose increased the percentage of morulae only in the presence of BSA alone. As opposed to observations in media containing BSA and

Table 6

Morula and blastocyst development of bovine embryos cultured in mSOF containing ultrafiltered, serum-free, oviduct conditioned medium (UBOCM) up to day 6 and subsequently in $8 \mathrm{~g} / 1$ BSA (UBOCM $>$ BSA), $\mathrm{UBOCM}+8 \mathrm{~g} / 1 \mathrm{BSA}(\mathrm{UBOCM}+\mathrm{BSA})$ or $8 \mathrm{~g} / 1$ BSA (BSA)

$R$ : Number of replicates per treatment; $n=$ number of oocytes. Values in the same column with different superscripts differ statistically.

\begin{tabular}{lrllllll}
\hline Treatment & $R$ & $n$ & \multirow{2}{*}{$\begin{array}{l}\text { \% Morulae } \\
\text { \% Blastocysts }\end{array}$} & \multicolumn{2}{l}{} \\
\cline { 5 - 8 } & & & Day 6 & Day 6 & \multicolumn{1}{c}{ Day 7 } & Day 8 & Day 9 \\
\hline (1) UBOCM & 10 & 324 & $38.9 \pm 3.4^{\mathrm{a}, \mathrm{b}}$ & 0.0 & $8.6 \pm 1.7^{\mathrm{x}}$ & $17.9 \pm 1.1^{\mathrm{x}}$ & $23.0 \pm 1.8^{\mathrm{a}}$ \\
(2) UBOCM > BSA & 10 & 321 & $42.3 \pm 5.0^{\mathrm{a}, \mathrm{b}}$ & 0.0 & $12.6 \pm 2.0^{\mathrm{x}}$ & $22.7 \pm 3.1^{\mathrm{x}, \mathrm{y}}$ & $26.7 \pm 3.9^{\mathrm{a}, \mathrm{b}}$ \\
(3) UBOCM + BSA & 6 & 180 & $46.8 \pm 6.3^{\mathrm{a}}$ & $1.8 \pm 1.2$ & $23.2 \pm 4.1^{\mathrm{y}}$ & $29.2 \pm 4.7^{\mathrm{y}}$ & $30.3 \pm 4.5^{\mathrm{a}, \mathrm{b}}$ \\
(4) BSA & 10 & 321 & $38.0 \pm 3.9^{\mathrm{b}}$ & 0.0 & $22.5 \pm 2.5^{\mathrm{y}}$ & $29.3 \pm 2.4^{\mathrm{y}}$ & $32.0 \pm 2.7^{\mathrm{b}}$ \\
\hline
\end{tabular}

${ }^{\mathrm{a}} p<0.05$.

${ }^{\mathrm{b}} p<0.05$.

${ }^{x} p<0.01$.

${ }^{\mathrm{y}} p<0.01$. 
Table 7

Morula and blastocyst development of bovine embryos cultured in mSOF containing ultrafiltered, serum-free, oviduct conditioned medium (UBOCM) up to day 6 and subsequently in 10\% FCS (UBOCM > FCS) or 10\% FCS (FCS)

$R$ : Number of replicates per treatment; $n=$ number of oocytes. Values in the same column with different superscripts differ statistically.

\begin{tabular}{llllllll}
\hline Treatment & $R$ & $n$ & \multirow{2}{*}{\begin{tabular}{l} 
\% Morulae \\
\cline { 5 - 7 }
\end{tabular}} & & & \multicolumn{2}{l}{ \% Blastocysts } \\
\cline { 5 - 7 } & Day 6 & Day 6 & \multicolumn{1}{c}{ Day 7 } & Day 8 & Day 9 \\
\hline (1) UBOCM & 6 & 179 & $36.1 \pm 4.6^{\mathrm{a}}$ & $0.0^{\mathrm{a}}$ & $7.2 \pm 1.9^{\mathrm{x}}$ & $17.7 \pm 1.2^{\mathrm{x}}$ & $24.4 \pm 1.7^{\mathrm{a}}$ \\
(2) UBOCM $>$ FCS & 6 & 173 & $37.5 \pm 3.8^{\mathrm{a}}$ & $0.0^{\mathrm{a}}$ & $25.0 \pm 2.4^{\mathrm{y}}$ & $31.7 \pm 2.2^{\mathrm{y}}$ & $33.7 \pm 2.4^{\mathrm{a}, \mathrm{b}}$ \\
$(3)$ FCS & 5 & 143 & $45.1 \pm 3.0^{\mathrm{b}}$ & $6.7 \pm 2.9^{\mathrm{b}}$ & $35.0 \pm 4.6^{\mathrm{y}}$ & $37.8 \pm 4.5^{\mathrm{y}}$ & $39.4 \pm 5.8^{\mathrm{b}}$ \\
\hline
\end{tabular}

${ }^{\mathrm{a}} p<0.05$.

${ }^{\mathrm{b}} p<0.05$.

${ }^{\mathrm{x}} p<0.01$.

${ }^{\mathrm{y}} p<0.01$.

FCS, no effects of glucose on blastocyst development were apparent in media containing UBOCM. However, blastocyst rates on Day 8 in BSA differed to that in FCS. The cell counts did not differ in the presence of glucose or any of the different protein supplements used.

\subsubsection{Experiment III}

In Table 6, the percentage of morulae increased when UBOCM and BSA were both together in culture. BSA did not increase blastocyst rates of Day 6 UBOCM-produced embryos, but blastocysts appeared earlier in UBOCM + BSA. There were no effects of UBOCM on blastocyst development rates in the presence of BSA. UBOCM was incapable of yielding blastocyst rates on Day 7 and 8 comparable to those of BSA alone.

\subsubsection{Experiment IV}

Table 7 shows that serum gave proportions of morulae and blastocysts higher than those in UBOCM. Furthermore, serum improved the blastocyst rate of Day 6 UBOCMproduced embryos.

\section{Discussion}

The procedure reported in this work permits the isolation of oviductal factors $>1,000 \mathrm{Da}$ and preserve their embryotrophic ability. The storage of a frozen retentate containing oviductal factors avoids either freezing original culture medium or repeated centrifugation of frozen-stored aliquots of conditioned medium (Vansteenbrugge et al., 1996), which is time consuming. In addition, the use of water instead of TCM-199 as a solvent for ultrafiltration prevents the presence of undesired factors in the retentate. 
Indeed, hypoxantine and nicotinamide, which have been found to inhibit embryo development (Bastia et al., 1993; Loutradis et al., 1993; Tsai and Gardner, 1994), are present in TCM-199 and should not be incorporated to SOF. Protein contents under our conditions were higher than that in the work of Vansteenbrugge (83 vs. $30 \mu \mathrm{g} / \mathrm{ml}^{-1}$, respectively), probably due in part to the lower level of cut-off employed in the present work. The method of storage prior to in vitro culture could also have affected the results, since the temperature and atmosphere used $\left(-193^{\circ} \mathrm{C}\right.$ and $\mathrm{LN}_{2}$ gas phase, respectively) contrast to $-90^{\circ} \mathrm{C}$ in air. All these different traits highlight the need to carry out simultaneous comparisons between both procedures.

Glucose affects in vitro embryo development depending on the origin of protein sources added to the culture medium. Glucose increased the percentage of morulae cultured in BSA, but did not promote yield of morulae in the presence of serum or oviductal factors. For blastocyst development, the most evident stimulatory effect of glucose was that on embryos cultured in serum. Interestingly, glucose did not affect development in the presence of oviductal factors, which agrees with a lack of correlation between glucose levels and embryotrophic activity of bovine oviduct conditioned medium (Stojkovic et al., 1997). In medium conditioned by BRL cells, the addition of glucose after 3 days of culture did not affect blastocyst yield (Funston et al., 1997). In the presence of BSA, glucose tended to promote development, which is in contrast with the notable difference found in other studies (Furnus et al., 1997).

The stimulation of blastocyst development by serum in simple media has already been demonstrated both in the presence (Rorie et al., 1994; Carolan et al., 1995; Koji et al., 1997; Wang et al., 1997; Donnay et al., 1999) and absence of exogenous glucose (Van Langendonckt et al., 1997; Vansteenbrugge et al., 1997; Thompson et al., 1998a). The FCS used in these experiments added $0.54 \mathrm{mM}$ glucose to culture media, whilst glucose contents were substantially lower in BSA and UBOCM (below 0.12 and 0.05 $\mathrm{mM}$, respectively).

Embryo quality may be assessed by the number of embryonic cells (Ellington et al., 1990). In the present study, the number of cells counted in expanded blastocysts did not differ due to the presence of glucose or any of the different protein supplements used. Glucose did not affect the cell number of blastocysts in SOF containing BSA (Takahashi and First, 1992; Van Langendonckt et al., 1997) or serum (Donnay et al., 1999). However, previously reported effects of serum and BSA on the cell number are contradictory, probably in dependence on specific bioactivity of batches used. It is likely that the effect of serum on cell number is dependent upon both, the time of its inclusion in culture and the type of serum itself. Embryos produced in UBOCM contained a number of cells comparable to other groups and exhibited excellent morphology.

In the present work, the addition of serum promoted the earlier appearance of blastocysts, which has been reported by other authors (Bavister et al., 1992; Bavister, 1995; Carolan et al., 1995; Koji et al., 1997; Van Langendonckt et al., 1997; Thompson et al., 1998a; Tricoire et al., 1999). The effect of FCS accelerating blastocyst development became apparent even after brief periods of culture (Koji et al., 1997; Van Langendonckt et al., 1997; Thompson et al., 1998a; these works reported differences in blastocyst rates because of serum addition at $36 \mathrm{~h}, 46 \mathrm{~h}$ and 2 days of culture, respectively). Recently, the shift in timing of blastocoele formation due to FCS addition 
to a simple medium containing amino acids, was reported in agreement with conditions in the present study using Day 6 UBOCM-produced embryos (24 h; Northey et al., 1999).

In Experiment II (Table 2), we observed that Day 6 morulae rates in UBOCM were comparable to those in the group containing BSA. However, development in UBOCM readily declined on Day 7 and blastocyst rates were lower. On this basis, we designed the experiments III and IV to investigate whether these Day 6 embryos produced in UBOCM were more competent when developing in other culture conditions (e.g., BSA or FCS), or whether lower blastocyst proportions would result in any case. As observed, UBOCM does not seem to be an appropriate medium to culture bovine embryos beyond the morula stage. FCS, but not BSA, resulted in more Day-6 UBOCM-cultured embryos reaching the blastocyst stage on Day 7. However, on Days 8 and 9 both FCS and BSA increased the blastocyst rates of UBOCM-cultured embryos. Although UBOCM in culture with BSA improved morula development, there was no effect on blastocyst development compared to culture in BSA alone. On this basis, we decided not to include a group containing UBOCM + FCS in experiment III. A possible explanation for these effects of BSA or FCS on UBOCM cultured embryos lies in the fact that although high molecular weight factors may enable the embryo to continue development during later stages (Gómez and Uría, 1997), they are actually unnecessary during the earlier stages (Mermillod et al., 1993; Pinyopummintr and Bavister, 1994; Vansteenbrugge et al., 1996; Gómez and Uría, 1997). Thus, the effects of increasing protein concentration on blastocysts yield would be more evident at a later stage (Wang et al., 1997; Krisher et al., 1998). In our work, blastocyst development in BSA was unaffected in the presence of UBOCM, which contains a low amount of protein. This suggests that a high BSA concentration at later stages is more important to the bovine embryo, in terms of blastocyst production, than are other factors provided by UBOCM. The above stimulatory effect could also be due to commercial BSA are likely to be contaminated with growth factors (Menezo and Khatchadourian, 1986; Carolan et al., 1995). Therefore, increasing the BSA concentration may increase the total growth factors contents.

A variety of nonspecific growth factors are secreted by the bovine oviduct (Watson et al., 1992; Eriksen et al., 1993; Schmidt et al., 1994; Gandolfi et al., 1995; Reinhart et al., 1998), and improve embryo development: FGF and EGF, acting synergistically or alone (Lee and Fukui, 1995), LIF (Fukui and Matsuyama, 1994), insulin and IGF-I (Matsui et al., 1995, 1997), a combination of TGF $\alpha$ and bFGF (Larson et al., 1992a), Activin $\beta$ A subunit (Yoshioka et al., 1998), PDGF (Larson et al., 1992b). As opposed to growth factors, oviductal molecules such as $97 \mathrm{kDa}$ bovine estrus associated glycoprotein and a tissue inhibitor of metalloproteinase- 1 do not seem to have an important role in sustaining embryo development in vitro (Vansteenbrugge et al., 1997).

In conclusion, the procedure employed here permits isolation of oviductal factors $>1,000 \mathrm{Da}$ and the preservation of their embryotrophic ability once in culture. However, this oviduct preparation does not support equivalent levels of blastocyst development at Day 7 as serum and BSA, nor does it accelerate blastocyst development. This might indicate that a lack of total protein was present in the retentate or that the type or levels of facilitative growth factors were ineffective. Oviductal factors are not an appropriate supplement for embryos beyond Day 6 of culture, and its embryotrophic 
effects are masked by the presence of BSA in culture. Blastocyst rates of embryos produced in the presence of oviductal factors may be enhanced by culturing them in the presence of serum or BSA. The effect of serum accelerating blastocyst development becomes apparent even during periods of culture as short as 1 day. Glucose affects in vitro embryo development depending on the protein sources added to the culture medium, although it did not increase the blastocyst cell number. In particular, glucose did not affect development in the presence of oviductal factors, which produced blastocysts of a quality comparable to those produced in serum or BSA.

\section{Acknowledgements}

Dr. P. Lonergan, for critical review and valuable suggestions, and technical staff of the Matadero Central de Asturias. This work was funded by a grant from FEDER, project 1FD97-0023.

\section{References}

Bastia, M.C., McGee-Belser, S.T., Bryan, S.H., Vazquez, J.M., 1993. In vitro deleterious effect of hypoxantine in Ham's nutrient mixture F-10 culture medium on human oocyte fertilization and early embryonic development. Fertil. Steril. 60, 876-880.

Bavister, B.D., 1995. Culture of preimplantation embryos: facts and artifacts. In: Human Reproduction Update Vol. 1 Oxford Univ. Press, New York, pp. 91-148, (2).

Bavister, B.D., Rose-Hellekant, T.A., Pinyopummintr, T., 1992. Development of in vitro matured/in vitro fertilized bovine embryos into morulae and blastocysts in defined culture media. Theriogenology 57, $127-146$.

Bradford, M.M., 1976. A rapid and sensitive method for the quantification of microgram quantities of protein utilizing the principle of protein-dye binding. Anal. Biochem. 72, 248-254.

Carolan, C., Lonergan, P., Van Langendonckt, A., Mermillod, P., 1995. Factors affecting bovine embryo development in synthetic oviduct fluid following oocyte maturation and fertilization in vitro. Theriogenology 43, 1115-1128.

Díez, C., Fernández, I., Gómez, E., 1998. Different patterns of in vitro development in bovine embryos cultured in serum-free bovine oviductal epithelial cell conditioned medium. In: Proceedings European Embryo Transfer Association Meeting. p. 146.

Donnay, I., Moens, A., Massip, A., Dessy, F., 1999. Bovine blastocysts development, apoptosis and metabolism following addition of glucose at the morula stage. Theriogenology 51, 236 .

Eckert, J., Pugh, P.A., Thompson, J.G., Niemann, H., Tervit, H.R., 1998. PVA and BSA have different effects on development and metabolism of bovine embryos produced in vitro. Theriogenology 49, 231.

Edwards, L.J., Batt, P.A., Gandolfi, F., Gardner, D.K., 1997. Modifications made to culture medium by bovine oviduct epithelial cells: changes to carbohydrates stimulate bovine embryo development. Mol. Reprod. Dev. 46, 146-154.

Ellington, J.E., Carney, E.W., Farrell, P.B., Simkin, M.E., Foote, R.H., 1990. Bovine 1-2 cell embryo development using a simple medium in three oviduct epithelial cell co-culture systems. Biol. Reprod. 43, 97-104.

Eriksen, T., Terkelsen, O., Hyttel, P., Mollgard, K., Greve, T., 1993. Regional morphology and localization of PDGF in bovine oviduct epithelium. Theriogenology 39, 15.

Eyestone, W.H., First, N.L., 1989. Co-culture of early cattle embryos to the blastocyst stage with oviductal tissue or in conditioned medium. J. Reprod. Fertil. 85, 715-720. 
Flood, L.P., Shirley, B., 1991. Reduction of embryo toxicity by protein in embryo culture media. Mol. Reprod. Dev. 30, 226-231.

Fukui, Y., Matsuyama, K., 1994. Development of in vitro matured and fertilized bovine embryos cultured in media containing human leukemia inhibitory factor. Theriogenology 42, 663-673.

Funston, R.N., Nauta, W.J., Seidel, G.E. Jr., 1997. Culture of bovine embryos in buffalo rat liver cell-conditioned media or with leukemia inhibitory factor. J. Anim. Sci. 75, 1332-1336.

Furnus, C.C., de Matos, D.G., Martínez, A.G., Matkovic, M., 1997. Effect of glucose on embryo quality and post-thaw viability of in vitro-produced bovine embryos. Theriogenology 47, 481-490.

Gandolfi, F., Modina, S., Brevini, T.A.L., Passoni, L., Artini, P., Petraglia, F., Lauria, A., 1995. Activin $\beta$ A subunit is expressed in bovine oviduct. Mol. Reprod. Dev. 40, 286-291.

Gómez, E., 1997. Acetoacetate and $\beta$-D-hydroxybutyrate as energy substrates during early bovine embryo development in vitro. Theriogenology 48, 63-74.

Gómez, E., Díez, C., 1998. Bovine embryos can use ketone bodies as energy substrates at different developmental stages in vitro. Theriogenology 49, 232.

Gómez, E., Uría, H., 1997. Morphological and functional characterization of bovine oviductal epithelial cells cultured on polarizing membranes. Reprod., Nutr., Dev. 37, 151-162.

Keskintepe, L., Burnley, C., Brackett, B., 1995. Production of viable blastocysts in defined in vitro conditions. Biol. Reprod. 52, 1410-1417.

Kim, J.H., Funahashi, H., Niwa, K., Okuda, K., 1993a. Glucose requirement at different developmental stages of in-vitro fertilised bovine embryos cultured in semi-defined medium. Theriogenology 39, 875-886.

Kim, J.H., Niwa, K., Lim, J.M., Okuda, K., 1993b. Effects of phosphate, energy substrates, and amino acids on development of in vitro-matured, in vitro-fertilized bovine oocytes in a chemically defined, protein-free culture medium. Biol. Reprod. 48, 1320-1325.

Koji, Y., Abas Mazni, O., Takahide, T., Harumichi, Y., Kenji, S., 1997. Differential patterns of blastulation in bovine morulae cultured in synthetic oviduct fluid medium containing FCS or BSA. Theriogenology 48, 997-1006.

Krisher, R.L., Lane, M., Bavister, B.D., 1998. Influence of semi-defined and defined culture media on the development, cell number and metabolism of bovine embryos. Theriogenology 49, 207.

Larson, R.C., Ignotz, G.C., Currie, W.B., 1992a. Transforming growth factor $\alpha$ and basic fibroblast growth factor synergistically promote early bovine embryo development during the fourth cell cycle. Mol. Reprod. Dev. 33, 432-435.

Larson, R.C., Ignotz, G.C., Currie, W.B., 1992b. Platelet derived growth factor (PDGF) stimulates development of bovine embryos during the during the fourth cell cycle. Development 115, 821-826.

Lee, E.S., Fukui, Y., 1995. Effect of various growth factors in a defined culture medium on in vitro development of bovine embryos matured and fertilized in vitro. Theriogenology 44, 71-83.

Lee, E.S., Pugh, P.A., Allen, N.W., Fukui, Y., Thompson, J.G., 1998. $\left[5-{ }^{3} \mathrm{H}\right]-$ Glucose and $\left[1-{ }^{14} \mathrm{C}\right]$-pyruvate utilization by fresh and frozen-thawed day 7 IVP bovine blastocysts cultured in PVA- or BSA-supplemented medium. Theriogenology 49, 233.

Lim, J.M., Kim, J.H., Okuda, K., Niwa, K., 1993. Effect of the presence of glucose during fertilization and/or culture in a chemically semi-defined medium on the development of bovine oocytes matured and fertilized in vitro. J. Reprod. Dev. 39, 237-242.

Lim, J.M., Kim, J.H., Okuda, K., Niwa, K., 1994a. The importance of $\mathrm{NaCl}$ concentration in a chemically defined medium for the development of bovine oocytes matured and fertilized in vitro. Theriogenology 42 , 421-432.

Lim, J.M., Okitsu, O., Okuda, K., Niwa, K., 1994b. Effects of fetal calf serum in culture medium on development of bovine oocytes matured and fertilized in vitro. Theriogenology 41, 1091-1098.

Loutradis, D.C.H., Kiessling, A.A., Kallianidis, K., Siskos, K., Creatsas, G., Michalas, S., Aravantinos, D., 1993. A preliminary trial of human zygote culture in Ham's F-10 without hypoxantine. J. Assist. Reprod. Genet. 10, 271-275.

Matsui, M., Takahashi, Y., Hishinuma, M., Kanagawa, H., 1995. Insulin and insulin-like growth factor-I (IGF-I) stimulate the development of bovine embryos fertilized in vitro. J. Vet. Med. Sci. 57, 1109-1111.

Matsui, M., Takahashi, Y., Hishinuma, M., Kanagawa, H., 1997. Stimulation of the development of bovine embryos by insulin and insulin-like growth factor-I (IGF-I) is mediated trough the IGF-I receptor. Theriogenology 48, 605-616. 
Maurer, H.R., 1992. Towards serum-free, chemical defined media for mammalian cell culture. In: Freshney, R.I. (Ed.), Animal Cell Culture: A Practical Approach. 2nd edn. Oxford Univ. Press, Oxford, pp. 15-46.

Menezo, Y., Khatchadourian, C., 1986. Peptides bound to albumin. Life Sci. 39, 1751-1753.

Mermillod, P., Vansteenbrugge, A., Wils, C., Mourmeaux, J.L., Massip, A., Dessy, F., 1993. Characterization of the embryotrophic activity of exogenous protein-free oviduct-conditioned medium used in culture of cattle embryos. Biol. Reprod. 49, 582-587.

Northey, D.L., Monson, R.L., Rutledge, J.J., Rutledge, M.L., 1999. Cattle blastocysts formation altered by the presence of fetal calf serum. Theriogenology 51, 250.

Ohboshi, S., Hanada, K., Zhao, J., Hattori, M., Fujihara, N., Umetsu, R., Yoshida, T., 1996. In vitro development of bovine one-cell embryos fertilized in vitro in serum- and feeder cell-free culture systems. As. Aust. J. Anim. Sci. 9, 583-590.

Parrish, J.J., Susko-Parrish, J.L., Leibfried-Rutledge, M.L., Critser, E.S., Eyestone, W.H., First, N.L., 1986. Bovine in vitro fertilization with frozen-thawed semen. Theriogenology 25, 591-600.

Pinyopummintr, T., Bavister, B.D., 1991. In vitro matured/in vitro fertilized bovine oocytes can develop into morulae/blastocyst in chemically defined, protein-free culture media. Biol. Reprod. 45, 736-742.

Pinyopummintr, T., Bavister, B.D., 1994. Development of bovine embryos in a cell-free culture medium: effects of type of serum, timing of its inclusion and heat inactivation. Theriogenology 41, 1241-1249.

Pinyopummintr, T., Bavister, B.D., 1996. Energy substrate requirements for in vitro development of early cleavage-stage bovine embryos. Mol. Reprod. Dev. 44, 193-199.

Reinhart, K.C., Dubey, R.K., Mummery, C.L., Van Rooijen, Keller, P.J., Marinella, R., 1998. Synthesis and regulation of leukaemia inhibitory factor in cultured bovine oviduct cells by hormones. Mol. Hum. Reprod. 4, 301-308.

Rieger, D., Loskutoff, N.M., Betteridge, K.J., 1992a. Developmentally related changes in the uptake and metabolism of glucose and glutamine by cattle embryos produced and co-cultured in vitro. J. Reprod. Fertil. 95, 585-595.

Rieger, D., Loskutoff, N.M., Betteridge, K.J., 1992b. Developmentally related changes in the uptake and metabolism of glucose, glutamine and pyruvate by cattle embryos produced in vitro. Reprod. Fertil. Dev. 4, $547-557$.

Rorie, R.W., Lester, T.D., Miller, G.F., Gliedt, D.W., McNew, R.W., 1994. Effects of protein source and co-culture on bovine embryo development in synthetic oviductal fluid medium. Theriogenology 42, 385-395.

Rosenkrans, C.F., Zeng, G.Q., McNamara, G.T., Schoff, P.K., First, N.L., 1993. Development of bovine embryos in vitro as affected by energy substrates. Biol. Reprod. 49, 459-462.

Schmidt, A., Einspanier, R., Amselgruber, W., Sinowatz, F., Schams, D., 1994. Expression of insulin-like growth factor 1 (IGF-1) in the bovine oviduct during the oestrus cycle. Exp. Clin. Endocrinol. 102, 364-369.

Stojkovic, M., Wolf, E., Van Langendonckt, A., Vansteenbrugge, A., Charpigny, G., Reinaud, P., Gandolfi, F., Brevini, T.A.L., Mermillod, P., Terqui, M., Brem, G., Massip, A., 1997. Correlations between chemical parameters, mitogenic activity and embryotrophic activity of bovine oviduct-conditioned medium. Theriogenology 48, 659-673.

Takahashi, Y., First, N.L., 1992. In vitro development of bovine one-cell embryos: influence of glucose, lactate, pyruvate, amino acids and vitamins. Theriogenology 37, 963-978.

Takahashi, Y., Hishinuma, M., Matsui, M., Tanaka, H., 1996. Development of in vitro matured/fertilized bovine embryos in a chemically defined medium: influence of oxygen concentration in the gas atmosphere. J. Vet. Med. Sci. 58, 897-902.

Thompson, J.G., Allen, N.W., McGowan, L.T., Bell, A.C.S., Lambert, M.G., Tervit, H.R., 1998a. Effect of delayed supplementation of fetal calf serum to culture medium on bovine embryo development in vitro and following transfer. Theriogenology 49, 1239-1249.

Thompson, J.G., Sherman, A.N., Allen, N.W., McGowan, L.T., Tervit, H.R., 1998b. Total protein content and protein synthesis within pre-elongation stage bovine embryos. Mol. Reprod. Dev. 50, 139-145.

Tricoire, H., Touzé, J.-L., Mermillod, P., 1999. Effect of fetal calf serum on the quality of in vitro produced cattle embryos. Theriogenology 51, 257.

Tsai, F.C.H., Gardner, D.K., 1994. Nicotinamide, a component of complex culture media, inhibits mouse 
embryo development in vitro and reduces subsequent developmental potential after transfer. Fertil. Steril. $61,367-382$.

Van Langendonckt, A., Donnay, I., Schuurbiers, N., Auquier, P., Carolan, C., Massip, A., Dessy, F., 1997. Effects of supplementation with fetal calf serum on development of bovine embryos in synthetic oviduct fluid medium. J. Reprod. Fert. 109, 87-93.

Vansteenbrugge, A., Van Langendonckt, A., Donnay, I., Massip, A., Dessy, F., 1996. Effect of high molecular weight factors present in bovine oviduct-conditioned medium on in vitro bovine embryo development. Theriogenology 46, 631-641.

Vansteenbrugge, A., Van Langendonckt, A., Massip, A., Dessy, F., 1997. Effect of estrus-associated glycoprotein and tissue inhibitor of metalloproteinase-1 secreted by oviduct cells on in vitro bovine embryo development. Mol. Reprod. Dev. 56, 527-534.

Wang, S., Liu, Y., Holyoak, G.R., Bunch, T.D., 1997. The effects of bovine serum albumin and fetal bovine serum on the development of pre- and post-cleavage-stage bovine embryos cultured in modified CR2 and M199 media. Anim. Reprod. Sci. 48, 37-45.

Watson, A.J., Hogan, A., Hahnel, A., Wiemer, K.E., Schultz, G.A., 1992. Expression of growth factor ligand and receptor genes in the preimplantation bovine embryo. Mol. Reprod. Dev. 31, 87-95.

Yoshioka, K., Suzuki, C., Iwamura, S., 1998. Effects of activin A and follistation on the development of bovine embryos cultured in vitro. In: Gametes: Development and Function. Serono Symposiap, p. 622. 